\title{
PEMANFAATAN DAUN UBI KAYU MENJADI DENDENG SEBAGAI MAKANAN ALTERNATIF VEGETARIAN PENGGANTI PROTEIN
}

\section{Utilization of Cassava Leaf Become Jerky as Protein Substitute of Vegetarian Alternative Food}

\section{Firdausni* dan Inda Three Anova}

Baristand Industri Padang

Jalan Raya LIK No. 23 Ulu Gadut, Padang. 25164

* e-mail: firdausni85@gmail.com

Diterima: 6 Maret 2015, revisi akhir: 4 Juni 2015, dan disetujui untuk diterbitkan: 12 Juni 2015

\begin{abstract}
ABSTRAK
Penelitian pemanfaatan daun ubi kayu dalam pembuatan dendeng sebagai sumber protein bertujuan untuk mengoptimalkan pemanfaatan daun ubi kayu menjadi produk olahan yang enak, disukai dan sebagai sumber protein bagi vegetarian. Pengolahan daun ubi kayu menjadi dendeng dilakukan dengan beberapa tahapan proses dan penambahan bahan pengisi, tepung, dan bumbu-bumbu yang lain sehingga dihasilkan dendeng yang empuk dengan rasa yang disukai. Tahap awal dilakukan untuk mendapatkan proses yang tepat dan variasi penambahan tepung yaitu kontrol $(0 \%)$ versi pengrajin, penambahan tepung tapioka 25,50 , dan $75 \%$. Hasil penelitian menunjukkan bahwa perbandingan penambahan tepung berpengaruh terhadap kadar protein, karbohidrat, dan organoleptik dendeng daun ubi kayu. Pembuatan dendeng daun ubi kayu dengan perlakuan penambahan tepung tapioka $50 \%$ menunjukkan hasil yang optimal dengan kadar air 2,91\%, kadar abu $4,47 \%$, protein $14,01 \%$, lemak $20,15 \%$, dan serat kasar $11,10 \%$, dan uji organoleptik rasa, warna, aroma dan tekstur disukai. Dendeng daun ubi kayu dengan kemasan plastik pada suhu ruang masih dalam kondisi baik secara visual selama tiga bulan penyimpanan.
\end{abstract}

\section{Kata Kunci: Dendeng, daun ubi kayu, protein.}

\section{ABSTRACT}

The research on utilization of cassava leaves in making of jerky as a protein source was aimed to optimilize the utilization of cassava leaves became products which were delicious, preferably and as a source of protein for vegetarians. The processing of cassava leaves became jerky was made by several stages of the process and addition of fillers, flour, and other seasoning condiment to produce a soft jerky with preferred taste. The first stage was done to get the right process and variation of flour addition, control $(0 \%)$ craftsmen version, the addition of tapioca flour $25 \%, 50 \%$ and $75 \%$. The results showed that the addition of flour ratio affected the levels of protein, carbohydrate and organoleptic of cassava leaves jerky. The making of cassava leaves jerky by treatment tapioca flour addition of $50 \%$ indicated optimal results with water content $2.91 \%$, ash content $4.47 \%$, protein $14.01 \%$, fat content $20.15 \%$, and crude fiber $11.10 \%$, and organoleptic testing for taste, color, aroma and texture were preferred. Observations storability of cassava leaves jerky with plastic packaging at room temperature was still in good condition visually for three months of storage.

Keywords: Jerky, cassava leaves, protein. 


\section{PENDAHULUAN}

Tanaman ubi kayu (Manihot uttilissima) merupakan sejenis umbi-umbian yang banyak diolah menjadi produk-produk yang mempunyai nilai ekonomi. Bagian tanaman ubi kayu yang umum digunakan sebagai bahan makanan adalah umbi dan daundaun muda (pucuk).

Daun ubi kayu biasa diolah menjadi berbagai olahan pangan, mengingat rasanya yang enak serta kaya kandungan gizi mengandung mineral, vitamin, asam amino essensial dan protein yang sangat baik bagi tubuh.

Unsur protein dalam daun ubi kayu berguna untuk membangun sel-sel tubuh dan komponen pembentuk enzim, sedangkan asam amino pada hijau daun berperan dalam mengubah karbohidrat menjadi energi, pemulihan luka pada kulit, mengganti sel-sel yang rusak, kesehatan tulang, membantu daya ingat, dan metabolism tubuh. Kandungan klorofil daun ubi kayu berfungsi sebagai antikanker dan antioksidan.

Sumber protein dari tanaman ubi kayu terdapat pada daun ubi kayu karena mengandung asam amino metionin. Daun muda (pucuk) ubi kayu sering digunakan sebagai sayuran aneka masakan lainnya. Kandungan gizi pucuk ubi kayu ternyata cukup tinggi. Dalam 100 gram pucuk ubi mengandung $6.8 \mathrm{gr}$ protein, $1.2 \mathrm{gr}$ lemak, $13.0 \mathrm{~g}$ karbohidrat, $2,4 \mathrm{~g}$ serat, $165 \mathrm{mg}$ Kalsium, $54 \mathrm{mg}$ fosfor, $2 \mathrm{mg}$ zat besi , dan beberapa mineral (Askar, 2014).

Daun ubi kayu selain dimanfaatkan sebagai sayuran dapat pula diolah menjadi pangan olahan yang dapat meningkatkan nilai jual, diantaranya untuk pembuatan dendeng. Dendeng adalah makanan berbentuk lempengan yang biasanya terbuat dari daging yang diberi bumbu dan dikeringkan. Kandungan air dendeng antara $3-40 \%$ bersifat plastis dan tidak terasa kering. Dendeng sebagai sumber protein hewani biasanya dibuat dari daging sapi. Tekstur dendeng daging sapi yang disukai biasanya empuk, namun kadang ditemui dendeng yang keras dan sering menyangkut di sela-sela gigi bila kita komsumsi, sedangkan dendeng daun ubi kayu diharapkan menyerupai dendeng daging tapi lebih gampang dikonsumsi bagi yang mempunyai masalah pada gigi. Dendeng daun ubi kayu sebagai sumber protein dapat dibuat melalui beberapa tahap merupakan sumber protein yang mudah dicerna tubuh. Melalui pengolahan daun ubi kayu menjadi dendeng diharapkan dapat menghasilkan produk yang disukai dengan nilai gizi yang baik sebagai sumber protein bersifat fungsional dengan kandungan serat nya yang cukup tinggi.

Serat pangan merupakan bagian tumbuhan yang dapat dimakan atau analog dengan karbohidrat yang tahan terhadap pencernaan dan absorpsi di dalam usus halus manusia mengalami fermentasi. Serat pangan meliputi polisakarida, karbohidrat, oligosakarida, lignin, dan bahan yang terkait dinding sel tanaman (waxes, cutin, suberin). Karbohidrat analog meliputi dekstrin tak cerna, pati resisten dan senyawa karbohidrat sintetis.

Sifat fungsional pangan muncul karena efek fisiologis yang ditimbulkan, efek fisiologis berkaitan dengan sifat fisik dan kimia meliputi: viskositas, fermentabilitas, kapasitas pengikatan air, absorpsi molekul organik dan sifat penukar ion (Marsono, 2004).

Dendeng merupakan suatu produk olahan daging secara tradisional yang telah banyak dilakukan masyarakat Indonesia sejak dulu. Dendeng dapat digolongkan ke dalam makanan setengah lembab asal daging (Intermediate Moisture Meat) karena kadar air dendeng berada dalam kisaran kadar air makanan setengah basah (Intermediate Moisture Food) yaitu 25\% (Purnomo,1997).

Pembuatan dendeng secara umum dapat melalui beberapa cara diantaranya dengan sayatan tipis dan dengan dicincang kasar setelah itu dicetak sehingga berbentuk lempengan (Susilawati, 2007). Kerusakan secara kimia pada dendeng yang banyak terjadi adalah oksidasi lemak dan pencoklatan non enzimatis. Kedua macam kerusakan tersebut dapat berperan pada penurunan nilai gizi, cita rasa maupun penampakan dendeng (Priyanto dan Gurnadi, 2010).

Pengolahan daun ubi kayu menjadi dendeng dapat menghasilkan dendeng dengan tekstur lebih renyah dan rasanya 
menyerupai dendeng daging. Pembuatan dendeng ubi kayu melalui substitusi tepung tapioka dilakukan untuk peningkatan mutu sehingga didapatkan dendeng sebagai sumber protein. Selain protein dendeng daun ubi kayu juga mengandung serat pangan sehingga dapat sebagai pangan fungsional. Kajian mengenai dendeng daun ubi kayu dari nilai gizi yang terkandung maupun tingkat kesukaan masyarakat penting, maka perlu perbaikan proses pembuatan, komposisi bahan dan uji mutu dendeng dapat diolah pada industri dalam skala industri kecil.

Pada pengolahan dendeng ubi kayu perlu penambahan bahan pendukung selain bahan baku daun ubi kayu bahan pengisi dan bahan pengikat. Fungsi penambahan bahan pengisi dan bahan pengikat pada pembuatan dendeng adalah untuk membentuk dan mereduksi penyusutan selama pemasakan.

\section{METODOLOGI PENELITIAN}

Bahan utama yang digunakan dalam penelitian ini adalah daun ubi kayu, telur, tepung tapioka, tepung beras, minyak goreng, ketumbar, bawang putih, garam dan bumbu bumbu lainnya dan bahan kimia pengujian $\mathrm{H}_{2} \mathrm{SO}_{4}, \mathrm{NaOH}, \mathrm{HCl}$, selen. Bahan baku daun ubi kayu dipilih daun muda dengan mutu bagus dari Pasar Raya Padang. Peralatan yang digunakan antara lain, crusher (penghancur), mixer listrik, peralatan memasak dan alat untuk pengujian timbangan analitik, kertas saring, erlenmeyer, cawan porselen,HPLC, labu Khjedahl, erlenmeyer, dan alat gelas lainnya.

Kegiatan penelitian dilakukan di laboratorium Baristand Industri Padang dan Laboratorium Pertanian Universitas Andalas Padang. Rancangan yang digunakan dalam penelitian ini adalah Rancangan Acak Lengkap (RAL) dengan 2 (dua) faktor yaitu jumlah penambahan tepung tapioka yang terdiri dari 4 perlakuan 0\%; 25\%; 50\% dan $75 \%$ dan perlakuan pemasakan (dikukus dan direbus) non faktorial dengan 3 kali ulangan.

\section{Pelaksanaan Penelitian}

Bahan baku yang digunakan dalam penelitian yaitu daun ubi kayu disortir, dipilih daun yang muda, dicuci, dan ditiriskan. Daun ubi kayu direbus selama 30 menit sampai 60 menit sampai daunnya lunak lalu ditiriskan. Selanjutnya daun ubi kayu dihaluskan dengan menggunakan crusher (penghancur) sehingga halus. Bahan-bahan penolong seperti bawang putih, ketumbar, bawang merah, jahe, dan lengkuas, dihaluskan dengan menggunanakan mesin penghancur.

Daun ubi kayu yang telah dihaluskan, ditambahkan dengan bumbu halus, telur, tepung tapioka, tepung beras dicampur jadi satu sampai homogen. Seterusnya dimasukkan ke cetakan dan direbus atau dikukus selama \pm 1 jam lalu diangkat dan didinginkan. Setelah dingin diiris tipis dan dipipihkan menyerupai dendeng daging. Dendeng digoreng dengan menggunakan minyak suhu $120^{\circ} \mathrm{C}$ (sedang) sampai berubah warna. Dendeng dikemas menggunakan plastik polipropilen dan di seal.

Produk yang diperoleh dianalisis melalui pengamatan fisika berupa karakteristik produk yang dihasilkan dan rendemen. Pengaruh substitusi tepung tapioka dan pengaruh pemasakan terhadap dendeng daun ubi kayu terhadap kadar air (metoda gravimetri), kadar abu (metoda gravimetri), protein (Metoda Khjedahl), lemak (Metoda soxhlet), kadar serat (Metoda gravimetri). Uji organoleptik meliputi rasa, warna, aroma dan tekstur oleh panelis berdasarkan skala hedonik (sangat suka - tidak suka). Ketahanan simpan produk setelah dikemas tertutup dengan plastik polipropilen di ruangan suhu kamar.

\section{HASIL DAN PEMBAHASAN}

\section{Karakteristik dan pengamatan fisik Dendeng daun ubi kayu.}

Pengamatan fisik dan kimia dilakukan terhadap dendeng daun ubi kayu yaitu warna, bau, rendemen dan kandungan $\mathrm{HCN}$ yang dihasilkan pada peningkatan proses pengolahan dan variasi bahan pengisi seperti pada Tabel 1. 
Tabel 1. Pengamatan dendeng ubi kayu melalui peningkatan proses pengolahan dan substitusi bahan pengisi.

\begin{tabular}{lll}
\hline No. & Parameter & Hasil Pengamatan \\
\hline 1 & Warna & $\begin{array}{l}\text { Kehitaman khas } \\
\text { dendeng }\end{array}$ \\
\hline 2 & Bau & Khas dendeng \\
\hline 3 & Rendemen & $\begin{array}{l}1340 \mathrm{~g}-1400 \mathrm{~g} \\
\text { dari } 1 \mathrm{~kg} \text { daun ubi } \\
\text { kayu segar }\end{array}$ \\
\hline 4 & HCN & Tidak terdeteksi \\
\hline
\end{tabular}

Karakteristik warna dendeng ubi kayu seperti dendeng daging lainnya (khas warna dendeng berbentuk lempengan tipis tanpa garis/serat). Ketebalan dendeng sesuai dengan yang diinginkan, semakin tipis maka dendeng akan semakin renyah. Rendemen dendeng sekitar $1340 \mathrm{~g}-1400 \mathrm{~g}$ dari $1 \mathrm{~kg}$ daun ubi kayu segar. Hal ini karena penambahan bahan pengisi dan pengikat serta bumbu lainnya. Melalui proses pengolahan yang baik akan dihasilkan dendeng daun ubi kayu dengan kandungan gizi yang tinggi sebagai sumber protein dan serat pangan.

Kandungan HCN (asam sianida) pengolahan daun ubi kayu setelah menjadi produk dendeng daun ubi kayu tidak terdeteksi. Menurut Sri Purwanti, 2005 bahwa kandungan asam sianida daun ubi kayu muda 560 - 620 ppm dan daun tua 400 -530 ppm, kandungan sianida akan berkurang melalui proses pencucian dan perebusan. Sianida merupakan racun yang berbahaya berupa getah putih, dalam keadaan alami berikatan dengan glukosida apabila jaringan sel tanaman dirusak maka enzim linamarase akan memutuskan ikatan senyawa tersebut dan membebaskan asam sianida (Hidayat et al., 2000).

\section{Pengaruh substitusi bahan pengisi dalam pengolahan daun ubi kayu menjadi dendeng.}

\section{Protein dendeng daun ubi kayu}

Penambahan tepung tapioka pada pembuatan dendeng daun ubi kayu menunjukkan peningkatan kandungan protein, semakin tinggi penambahan tapioka maka semakin meningkat persentase protein.

Lina (2014) menyatakan bahwa daun ubi kayu selain mengandung mineral, vitamin, asam amino essensial juga protein yang sangat baik untuk tubuh. Cara pemasakan juga berpengaruh terhadap kadar protein, dimana pengukusan merupakan cara terbaik dibandingkan dengan pemanasan terhadap kadar protein, seperti terlihat pada Gambar 1

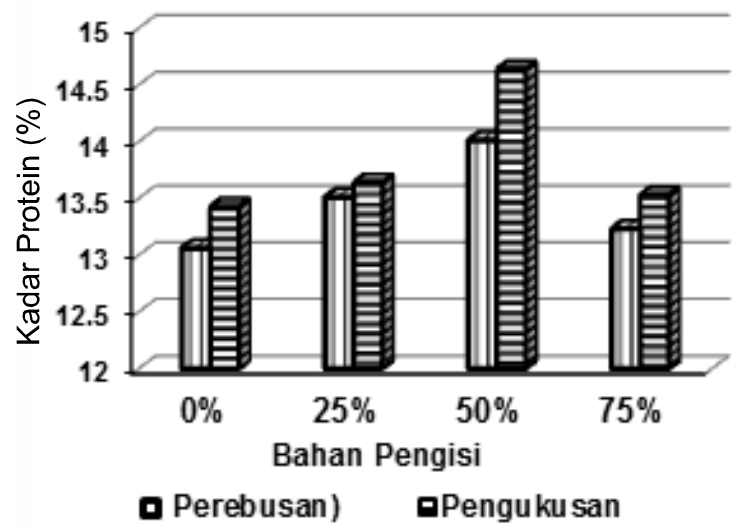

Gambar 1. Kadar protein dendeng daun ubi kayu pada substitusi bahan pengisi tapioka.

Kadar protein dendeng daun ubi kayu pada beberapa perlakuan 13,06\%-14,64\%, dengan kadar protein terendah pada perlakuan kontrol 13,06\%. Tepung tapioka berfungsi sebagai bahan pengisi dan pengikat daun ubi kayu. Menurut Haryanto et al., dalam Angraini (2002) menyatakan dalam $100 \mathrm{~g}$ tepung tapioka mengandung kadar air 9,20\%, lemak 0,3\%, karbohidrat $80,9 \%$ dan protein $0,5 \%$. Hal ini menyatakan bahwa tepung tapioka tidak sebagai sumber protein. Proses pengolahan perebusan dan pengukusan memberikan pengaruh yang nyata dimana melalui pengukusan akan menghasilkan protein lebih tinggi dari perebusan. Proses pemasakan akan mempengaruhi kadar protein dendeng. Perebusan menyebabkan bahan langsung bersentuhan dengan air sehingga sebagian protein akan terlarut di dalamnya, berbeda dengan pengukusan yang menggunakan uap air dalam proses pemasakannya.

Menurut Askar (2014) daun singkong memiliki kandungan mineral, vitamin, asam amino, dan protein yang sangat baik bagi 
tubuh. Protein daun ubi kayu sekitar $6,8 \%$ dalam 100 gr daun ubi kayu Daun ubi kayu mempunyai kadar protein yang lebih tinggi dibandingkan dengan ubi kayu. Proses pengolahan yang melibatkan pemanasan, bahan kimia, dan perlakuan mekanik mengakibatkan perubahan struktur kimia protein. Penambahan tepung tapioka $75 \%$ pada pembuatan dendeng mengandung kadar protein tertinggi. Tepung tapioka mempunyai pati yang tinggi, pati ubi kayu mempunyai suhu gelatinisasi yang rendah.

Menurut Pomeranz (1991), suhu gelatinisasi tapioka berkisar antara $52-64^{\circ} \mathrm{C}$. Perbedaan kadar protein pada perlakuan mungkin disebabkan daya serap tapioka terhadap daun singkong, dimana penambahan tepung tapioka $50 \%$ merupakan perlakuan yang baik dengan kadar protein yang tinggi dibandingkan dengan perlakuan lainnya. Tepung tapioka mempunyai pati, dimana granula pati terdiri dari dua fraksi yang dipisahkan dengan air panas, fraksi terlarut disebut amilosa dan fraksi tidak terlarut amilopektin (Winarno, 2002).

\section{Serat kasar dendeng daun ubi kayu}

Serat bahan pangan merupakan karbohidrat atau polisakarida. Menurut Winarno (2004) serat kasar pada tanaman atau bahan makanan, terdapat pada dinding sel yang secara kimia dinding sel tersebut terdiri dari beberapa jenis karbohidrat seperti selulosa, hemiselulosa, pektin dan nonkarbohidrat seperti polimer lignin, beberapa gum, dan mucilage.

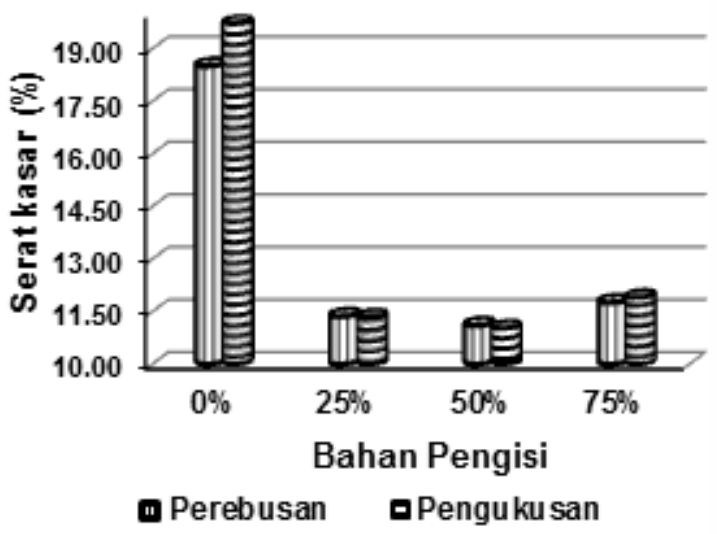

Gambar 2. Kadar serat kasar dendeng daun ubi kayu pada substitusi bahan pengisi tapioka
Serat kasar penting dalam penilaian bahan makanan yang merupakan indeks dan menentukan nilai gizi makanan. Serat kasar adalah bagian yang tidak dapat dihidrolisis oleh asam atau basa kuat. Dengan adanya serat membantu mempercepat sisa makanan melalui saluran pencernaan untuk dieksresikan keluar (Parman et al., 2008).

Analisis serat kasar pada dendeng daun singkong dengan berbagai perlakuan berkisar antar $11,10 \%-19,71 \%$. Tingginya hasil analisis serat kasar pada dendeng disebabkan daun singkong merupakan sumber serat yang tinggi. Perlakuan kontrol dengan serat kasar tertinggi, hal ini disebabkan karena banyaknya daun singkong yang ditambahkan dibandingkan dengan perlakuan lainnya, sedangkan perlakuan lainnya mempunyai persentase serat kasar yang hampir sama. Serat kasar merupakan komponen sisa hasil hidrolisis suatu bahan dengan asam kuat sehingga terjadi kehilangan selulosa sekitar $50 \%$ dan hemiselulosa $85 \%$.

Perlakuan pemasakan tidak berpengaruh nyata terhadap serat kasar. Perebusan dan pengukusan pada pengolahan dendeng memberikan serat kasar yang hampir sama. Serat kasar tertinggi pada perlakuan kontrol dengan cara pengukusan $19,71 \%$. Hal ini disebabkan kandungan serat kasar tidak larut dengan pemanasan direbus maupun dikukus.

\section{Jumlah Kalori}

Jenis makanan mempunyai jumlah kalori yang bervariasi. Tubuh manusia membutuhkan kalori untuk bertahan hidup. Jumlah kalori pada dendeng daun ubi kayu merupakan kalori yang dihasilkan dari jumlah karbohidrat, protein dan lemak. Pada $1 \mathrm{~g}$ karbohidrat mengandung 4 kalori, $1 \mathrm{~g}$ protein mengandung 4 kalori dan $1 \mathrm{~g}$ lemak mengandung 9 kalori. Jumlah kalori pada dendeng daun ubi kayu seperti pada Gambar 3.

Jumlah kalori dendeng daun ubi kayu $420,73 \mathrm{kal}$ - 433,76 kal, nilai kalori yang rendah pada perlakuan penambahan tepung tapioka $75 \%$. Apabila dilihat pada jumlah kalori dendeng daging yaitu (85-326 $\mathrm{kal} / 100 \mathrm{~g}$ bahan), nilai kalori dendeng daun 
ubi kayu lebih tinggi. Hal ini disebabkan dendeng daun ubi kayu dibuat dengan penambahan bahan tambahan lainnya seperti telur, tepung tapioka, tepung beras, dan tambahan lainnya.

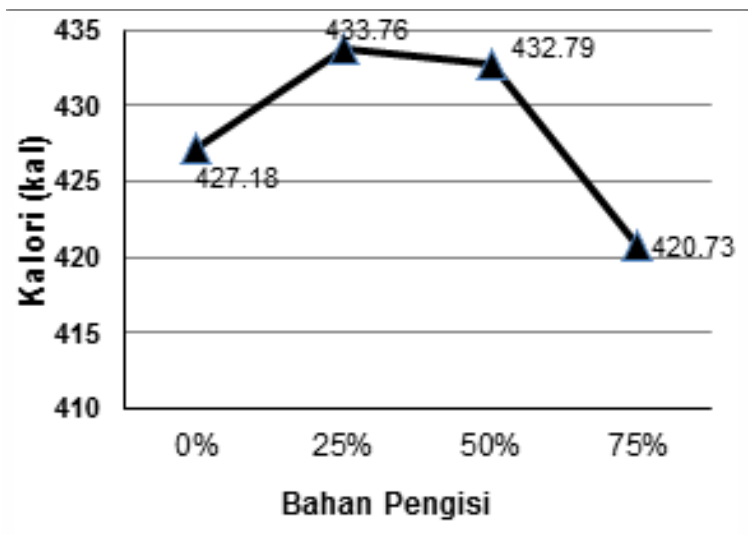

Gambar 3. Jumlah kalori dendeng daun ubi kayu melalui sistem perebusan pada substitusi bahan pengisi tapioka.

Jumlah kalori didapat dari kalori yang didapat dari protein, karbohidrat dan lemak. Proses pemanasan bahan kimia, perlakuan mekanik dan $\mathrm{pH}$ mengakibatkan perubahan struktur kimia protein. Fungsi utama protein termasuk membangun dan memperbaiki jaringan tubuh, regulasi proses tubuh dan pembentukan enzim dan hormon. Selain itu protein juga membantu dalam pembentukan antibodi dan protein juga sebagai pemasok energi utama(Suryati et al., 2014).

\section{Komponen kimia lainnya produk dendeng dari daun ubi kayu}

Dendeng daun ubi kayu selain mengandung protein juga mengandung beberapa komponen penting lainnya yang berpengaruh terhadap mutu.

Tabel2. Nilai analisa kimia dendeng dari daun ubi kayu.

\begin{tabular}{lllc}
\hline No & Kriteria Uji & $\begin{array}{l}\text { Nilai rata- } \\
\text { rata (\%) }\end{array}$ & $\begin{array}{l}\text { SNI } \\
\text { Dendeng }\end{array}$ \\
\hline 1 & Air b/b & $2,27-6,05$ & Maks 12\% \\
\hline 2 & Abu b/b. & $1,68-4,47$ & Maks 1,0 \\
\hline 3. & $\begin{array}{l}\text { Lemak } \\
\text { (b/b) }\end{array}$ & $17,10-20,48$ & - \\
\hline
\end{tabular}

Kadar Air

Kadar air dendeng daun ubi kayu $(2,27 \%-5,05 \%)$ dan bervariasi tergantung perlakuan. Kadar air dendeng memenuhi syarat semua perlakuan dimana SNI dendeng kadar air maks $12 \%$. Dendeng daun ubi kayu dari pengrajin mempunyai kadar air yang tinggi $5,05 \%$. Semakin tinggi persentase tepung tapioka ditambahkan menghasilkan kadar air dendeng yang tinggi. Husein (2009) mengatakan bahwa tepung tapioka mengandung pati yang cukup tinggi dan saat pemanasan terjadi gelatinasi, sehingga air akan terperangkap. Dendeng dengan penambahan $75 \%$ tapioka menghasilkan kadar air 4,36\%, lebih rendah dibandingkan dengan dendeng versi pengrajin.

Kadar air merupakan komposisi yang penting dalam pangan, karena kadar air sangat menentukan kadar komponen lainnya dan dinyatakan dalam basis basah dan basis kering. Tinggi atau rendahnya kadar air dalam bahan pangan akan menentukan mutu akhir dari dendeng bila dikonsumsi masyarakat

\section{Kadar Abu}

Abu adalah zat anorganik sisa hasil pembakaran suatu bahan organik dan kadar abu suatu bahan tergantung bahan dan cara pengabuannnya (Sudarmadji, 1984). Pada penelitian ini, perhitungan kadar abu memakai metoda langsung memakai tanur dengan prinsip kerja mengoksidasikan (pembakaran) semua zat organik pada suhu tinggi, yaitu sekitar $500-600^{\circ} \mathrm{C}$ dan kemudian melakukan penimbangan zat yang tertinggal setelah proses pembakaran tersebut (Sudarmadji, 1984). Kadar abu dendeng daun ubi kayu $1,68-4,47 \%$ sedangkan pada penelitian Saputra (2013) kadar abu dendeng lumat ikan patin 5,75\%. Kadar abu erat kaitannya dengan mineral yang dikandung oleh suatu bahan tersebut. Winarno (2002) menyatakan bahwa unsur mineral tersebut terdapat dalam bentuk organik, garam anorganik, atau sebagai bentuk senyawa kompleks yang bersifat organik dan penentuan kadar abu sering kali dilakukan untuk mengendalikan garamgaram anorganik seperti garam kalsium. Dalam proses pembakaran, bahan organik 
terbakar tetapi zat anorganiknya tidak terbakar.

\section{Kadar Lemak}

Hasil analisa terhadap kadar lemak dendeng daun ubi kayu dengan beberapa perlakuan $17,32 \%-20,48 \%$, dimana perlakuan penambahan tepung tapioka $25 \%$ mempunyai kadar lemak tertinggi.

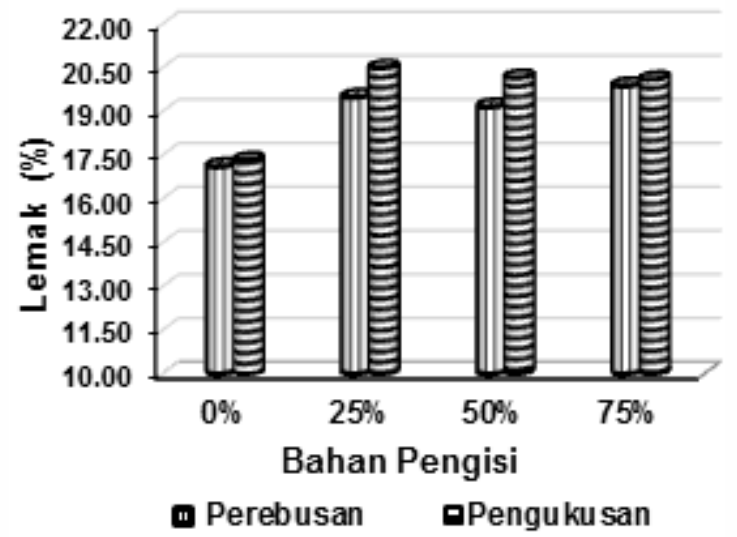

Gambar 3. Kadar lemak dendeng daun ubi kayu pada substitusi bahan pengisi tapioka

Penambahan bahan pengisi pada pembuatan dendeng daun ubi kayu berpengaruh tidak nyata dimana lemak tertinggi pada $25 \%$ tapioka melalui proses pengukusan $20,48 \%$, sedangkan terendah pada kontrol (\% tapioka) $17,32 \%$. Daun ubi kayu mempunyai kadar lemak yang rendah. Menurut Lakitan (1995) bahwa daun ubi kayu mempunyai kadar lemak 1,2\%, sedangkan tepung tapioka mempunyai kadar lemak 0,2\%. Kadar lemak mempengaruhi tekstur produk dimana kadar lemak yang optimal akan menghasilkan tampilan produk yang baik.

\section{Tingkat kesukaan panelis terhadap dendeng dengan bahan daun ubi kayu pada substitusi tepung tapioka}

\section{Penampakan dan Tekstur}

Uji organoleptik dilakukan panelis terhadap tekstur, aroma, rasa dan dendeng daun ubi kayu seperti pada Tabel 3. Nilai organoleptik terhadap penampakan dendeng daun ubi kayu disukai panelis dengan nilai 3,85-4,11. Perlakuan substitusi tepung tapioka meningkatkan nilai penampakan dendeng. Tepung tapioka sebagai bahan pengisi dapat memberikan tampilan dan penampakan yang lebih baik dibandingkan kontrol. Sedangkan tekstur dendeng juga disukai panelis. Tekstur dendeng daun ubi kayu lebih halus tanpa serat dibandingkan dengan dendeng dari daging, ini menyebabkan dendeng daun ubi kayu lebih renyah dan krispi tanpa ada serat sehingga memudahkan dalam mengkonsumsinya.

Tabel3. Nilai rata-rata hasil uji organoleptik terhadap penampakan dan tekstur dendeng dari daun ubi kayu.

\begin{tabular}{ccc}
\hline Perlakuan & Penampakan & \multicolumn{2}{c}{ Tekstur } \\
\hline $75 \%$ & $4,11 \mathrm{a}$ & $3,20 \mathrm{c}$ \\
$50 \%$ & $4,11 \mathrm{a}$ & $4,20 \mathrm{a}$ \\
$25 \%$ & $3,89 \mathrm{~b}$ & $3,80 \mathrm{~b}$ \\
$0 \%$ & $3,85 \mathrm{~b}$ & $3,60 \mathrm{~b}$ \\
\hline
\end{tabular}

Keterangan : Angka-angka pada lajur yang sama diikuti huruf kecil yang sama, berbeda tidak nyata menurut DNMRT pada taraf $5 \%$.

\section{Aroma, rasa, dan warna.}

Kesan pertama konsumen terhadap suatu produk adalah dengan melihat bentuk dan warna yang menarik selanjutnya aroma yang dapat dideteksi oleh indra penciuman dan yang penting rasa dari produk makanan tersebut. Nilai organoleptik terhadap aroma, warna dan rasa dendeng daun ubi kayu dapat dilihat pada Tabel 4 .

Tabel4. Nilai rata-rata hasil uji organoleptik terhadap aroma, rasa dan Warna dendeng daun ubi kayu

\begin{tabular}{cccc}
\hline $\begin{array}{c}\text { Perla- } \\
\text { kuan }\end{array}$ & Aroma & Rasa & Warna \\
\hline $0 \%$ & $3,90 \mathrm{~b}$ & $3,95 \mathrm{ab}$ & $3,20 \mathrm{~b}$ \\
$25 \%$ & $4,00 \mathrm{a}$ & $4,05 \mathrm{a}$ & $3,24 \mathrm{~b}$ \\
$50 \%$ & $4,16 \mathrm{a}$ & $4,16 \mathrm{a}$ & $3,59 \mathrm{a}$ \\
$75 \%$ & $4,00 \mathrm{a}$ & $3,89 \mathrm{~b}$ & $3,24 \mathrm{~b}$
\end{tabular}

Keterangan : Angka-angka pada lajur yang sama diikuti huruf kecil yang sama, berbeda tidak nyata menurut DNMRT pada taraf $5 \%$. 
Hasil penelitian terhadap aroma, rasa dan warna dendeng daun ubi kayu dapat dilihat pada Tabel 4. Penambahan tepung tapioka memberikan nilai aroma lebih rendah dibandingkan kontrol. Hal ini disebabkan komposisi daun ubi kayu lebih sedikit dibandingkan kontrol sehingga waktu proses terakhir aromanya kurang muncul. Daun ubi kayu mempunyai kandungan berbagai mineral sehingga pada proses pemasakan akan menghasilkan aroma spesifik. Tingkat kesukaan panelis terhadap rasa bervariasi dimana penambahan tepung tapioka 50\% menghasilkan rasa yang tinggi. Perlakuan kontrol tanpa penambahan tepung tapioka memberikan nilai rasa yang rendah, karena komposisi daun ubi kayu yang lebih dominan menyebabkan rasa dendeng lebih rendah. Begitu juga penambahan tepung tapioka yang tinggi juga akan menurunkan nilai rasa dendeng. Melalui penambahan komposisi tepung tapioka dan daun ubi kayu yang sesuai akan menghasilkan cita rasa dendeng yang tinggi.

Organoleptik warna dendeng disukai $(3,20-3,59)$, dengan nilai warna tertinggi pada perlakuan penambahan $50 \%$ tapioka yaitu 3,59 disukai sampai sangat disukai. Astawan (2008) menyebutkan bahwa warna makanan dapat menggugah selera, dalam seni tata saji, warna merupakan faktor penting yang harus diperhatikan. Padu padan warna yang apik, merupakan salah satu faktor yang akan menjadi nilai jual suatu hidangan. Winarno (1997) menambahkan, warna bahan pangan tergantung pada penampakan bahan pangan tersebut dan kemampuan dari bahan pangan memantulkan, menyebarkan, atau menyerap sinar.

\section{KESIMPULAN}

Daun ubi kayu dapat diolah menjadi dendeng dengan hasil uji organoleptik disukai panelis. Perlakuan penambahan tepung tapioka memberikan pengaruh pada tingkat kesukaan panelis terhadap tekstur, rasa, dan penampakan dengan kadar protein 13,06-14,01\%, serat kasar 11,02$19,71 \%$ dan lemak 17,32-,48\%. Penambahan tepung tapioka $50 \%$ memberikan hasil optimal dengan kadar air $2,91 \%$, protein $14,01 \%$, lemak $20,15 \%$, serat kasar $11,10 \%$, dan abu $4,47 \%$ dengan nilai organoleptik terhadap aroma 4,16 (disukai), rasa 4,16 (disukai- sangat suka), warna 3,59 (suka), penampakan 4,11 (suka-sangat disukai), tekstur 4,20 (suka-sangat disukai).

\section{DAFTAR PUSTAKA}

Angraini, N. 2002. Pengaruh konsentrasi tepung tapioka, suhu dan waktu perebusan terhadap mutu kamaboko ikan bawal air tawar (Colossoma Macropomum).

Askar, S. 2014. Daun ubi kayu dan pemanfaatannya terutama sebagai pakan tambahan. JITV. 19.2.

Astawan, M. 2008. Khasiat warna-warni makanan. Gramedia Pustaka Utama.

Clark, M. J., \& Slavin, J. L. 2013. The effect of fiber on satiety and food intake: a systematic review. Journal of the American College of Nutrition, 32, 200-11.

Hidayat, A., Zuaraida, N., Hanarida, I., \& Damardjati, D. S. 2000. Cyanogenic content of cassava root of 179 cultivars grown in Indonesia. Journal of Food Composition and Analysis, 13(1), 71-82.

Husein, R. N. 2009. Pegaruh penambahan tepung tapioka terhadap mutu dendeng ikan runcah. Skripsi Jurusan Teknologi Hasil Perikanan. Universitas Riau. Pekanbaru.

Lakitan, B. 1995. Pemuliaan tanaman secara in vitro dengan memanfaatkan variasi somaklonal : prospek dan masalahnya. Seminar Bioteknologi dan Pelatihan Teknologi DNA. Fakultas Pertanian UISU, Medan.

Lina, W. 2014. Ibm dusun Ranupakis dalam pemanfaatan daun ubi kayu menjadi abon dan nugget melalui PKK dan Koperasi di Kecamatan jatirotolumajang. 
Marsono, Y. 2004. Serat pangan dalam perspektif ilmu gizi. Pidato pengukuhan Guru Besar. Majelis Guru Besar Universitas Gadjah Mada, Jogjakarta.

Parman, Sarjana, dan Harnina, S. 2008. Pertumbuhan, kandungan klorofil dan serat kasar pada defoliasi pertama Alfalfa (Medicago sativa L) akibat pemupukan mikorisa. Jurnal Anatomi Fisiologi.

Pomeranz, Y. 1991. Starch and enzymeresistant starch from high-amylose barley. Cereal Chem, 68(6), 589-596.

Priyanto, R., dan E. Gurnadi. 2010. Sifat fisiko-kimia dendeng daging giling terkait cara pencucian (leaching) dan jenis daging yang berbeda. Media Peternakan-Journal of Animal Science and Technology31.2.

Purnomo, H.1997. Studi tentang stabilitas protein daging kering dan dendeng selama penyimpanan. Laporan penelitian. FP-Unibraw Press, Malang.

Purwanti, S. 2005. Pengaruh perlakuan terhadap kadar asam sianida ( $\mathrm{HCN})$ kulit ubi kayu sebagai pakan alternatif.

Saputra, J. 2013. Studi pengolahan dendeng lumat ikan patin (pangasius hyphopthalmus). Tesis Fakultas Perikanan IImu Kelautan Universitas Riau.
Sudarmadji, S., Haryono, B., dan Suhardi. 1984. Prosedur analisa untuk bahan makanan dan pertanian. Yogyakarta. Liberty. 178.

Sujana, E., Wahyuni, S., dan Burhanuddin, H. 2006. Efek pemberian ransum yang mengandung tepung daun singkong, daun ubi jalar, dan eceng gondok sebagai sumber pigmen karotenoid terhadap kualitas kuning telur itik Tegal. Jurnal Ilmu Ternak.

Suryati, T., Astawan, M., Lioe, H. N., Wresdiyati, T., \& Usmiati, S. 2014. Nitrite residue and malonaldehyde reduction in dendeng - Indonesian dried meat - influenced by spices, curing methods and precooking preparation. Meat Science, 96.

Susilawati, I. 2007. Kajian metode pengasapan dalam pengolahan dendeng batokok produk khas Sumatera Barat. Laporan Penelitian. Institut Pertanian Bogor. Bogor.

Winarno, FG. 2002. Kimia pangan dan gizi. Jakarta. Gramedia. 